\title{
Some long-term effects of scoliosis diagnosed at school age
}

\author{
O Nowotny-Czupryna ${ }^{1,2^{*}}$, A Kowalczyk, K Czupryna $^{1,2}$, J Nowotny ${ }^{1}$, M Plaszewski $^{2}$ \\ From 8th International Conference on Conservative Management of Spinal Deformities and SOSORT 2011 \\ Annual Meeting \\ Barcelona, Spain. 19-21 May 2011
}

\section{Background}

Abnormal arrangement of the body may lead to the development of overload syndrome, nerve roots irritation, pain, ventilator impairment and also worsening of physical fitness [1-3].

\section{Objective}

Checking how, after years low degree scoliosis impairs breathing, reduces performance and generates back pain was the aim of the study.

\section{Materials and methods}

Respiratory function, working capacity (PWC170) and pain intensity (Jackson and Moskowitz regimen) were assessed in 39 adults, aged from 19 to 38 years, who were diagnosed in adolescence with low degree scoliosis $\left(10^{\circ}-28^{\circ}\right)$. Also, 43 controls with no scoliosis in adolescence were examined.

\section{Results}

There was no progression of the curvature after the treatment. Spirometric results among scoliotic subjects were slightly lower than in the controls, although it did not show the characteristics of the restrictive type of respiratory disorder, which was found in $5.1 \%$ of patients. PWC170 test results were significantly lower (by about $20 \%$ ) than in controls, and $84.6 \%$ subjects reported periodical, occasional of frequent, mostly lumbar pain associated with the work performed. In $12.8 \%$ cases pain impeded breathing. In about half of the group pain occurred especially after physical effort and caused limitation of activity, while in other subjects did not affect daily activities.

${ }^{1}$ Medical University of Silesia in Katowice Katowice, Poland

Full list of author information is available at the end of the article

\section{Conclusions}

1) subjects with low degree scoliosis generally do not indicate impairment of lung ventilation with the characteristics of restrictive disorders; 2) adults with settled low degree scoliosis characterized by lack of physical fitness, in the form of reductions in PWC170; 3) the presence of school-age low degree scoliosis predisposes to the occurrence of pain symptoms in adulthood.

\section{Author details}

'Medical University of Silesia in Katowice Katowice, Poland. ${ }^{2}$ Institute of

Physiotherapy - Higher School of Administration in Bielsko-Biała, Poland.

Published: 27 January 2012

\section{References}

1. Kearon C, Viviani GR, Killian KJ: Factors influencing work capacity in adolescent idiopathic thoracic scoliosis. Am Rev Respir Dis 1993, 148(2):295-303.

2. Kesten S, Garfinkel SK, Wright T, Rebuck AS: Impaired exercises capacity in adults with moderate scoliosis. Chest 1991, 99:663-666.

3. Weiss HR, Werkmann M: Unspecific low back pain - a simple classification tested in a case series of patients with spinal deformities. Scoliosis 2009, doi: 10.1186/1748-7161-4-4.

doi:10.1186/1748-7161-7-S1-O8

Cite this article as: Nowotny-Czupryna et al: Some long-term effects of scoliosis diagnosed at school age. Scoliosis 2012 7(Suppl 1):O8.

Submit your next manuscript to BioMed Central and take full advantage of:

- Convenient online submission

- Thorough peer review

- No space constraints or color figure charges

- Immediate publication on acceptance

- Inclusion in PubMed, CAS, Scopus and Google Scholar

- Research which is freely available for redistribution 